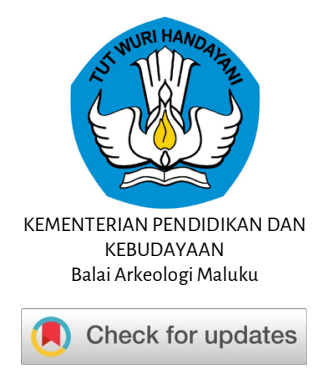

Kapata Arkeologi, 16(1) 2020, 27-40

p-ISSN: 1858-4101, e-ISSN: 2503-0876

KAPATA ARKEOLOGI

SCIENTIFIC Journal of ARCHAEOLOGY AND CULTURAL StUdiES

Accredited by the Indonesian Ministry of Research, Technology, and Higher Education (RISTEKDIKTI)
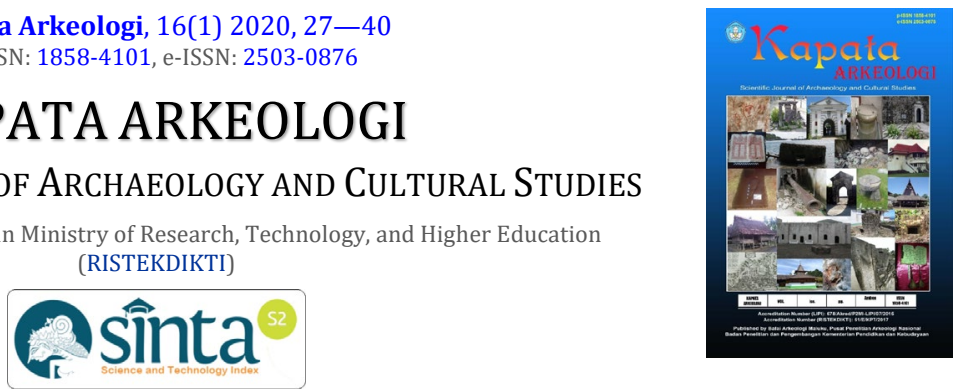

http://kapata-arkeologi.kemdikbud.go.id/

\title{
ARCHAEOLOGICAL OBJECT AS TOURISM IN SAMOSIR ISLAND
}

\author{
Femmy Indriany Dalimunthe (iD) 1 , Ketut Wiradnyana (iD) 2 \\ ${ }^{1}$ Politeknik Pariwisata Medan \\ Jl. Rumah Sakit Haji No. 12, Medan 20371, Indonesia \\ ${ }^{2}$ Balai Arkeologi Sumatera Utara \\ Jl. Seroja Raya Gg. Arkeologi No.1, Medan 20135, Indonesia \\ ${ }^{1}$ femmydalimunthe@poltekparmedan.ac.id; ${ }^{2}$ ketut.wiradnyana@kemdikbud.go.id \\ Received: 29/05/2020; revisions: 04/08 — 10/09/2020; accepted: 20/10/2020
}

\begin{abstract}
Samosir Island is in the middle of Lake Toba as part of a geological process related to Mount Toba's eruption. The existence of the lake itself becomes an attraction for a tourist attraction. There are various archaeological remains in the form of megalithic objects related to the Toba Batak community death ceremony tradition, which has lasted a long time. The procession of death and customs, which are still ongoing today, is considered a tourist attraction that will attract tourists if developed. The management of megalithic tradition as tourism objects in this region is relatively inadequate. Efforts to identify these objects are required, accompanied by descriptions of scientific information and building an ideal tourism concept. Therefore, burial container and other archaeological objects are the study's description, accompanied by the concept of developing tourism with local character as part of the discussion. The method in this research is descriptive analysis and literature study. Archaeological objects are described and interpreted inductively. The results of this study concluded that the archaeological remains on Samosir Island are dominated by burial containers, which belong to the megalithic tradition. This megalithic tradition is closely related to the conception of death ceremonies which is still sustained in the Batak Toba community today. The relationship between archaeological objects and community traditions can be packaged into tourism ideas of particular interest of local character. Tourism management that involves local communities is expected to impact economically and maintain both the traditions and archaeological objects themselves. This idea is also considered to have great potential for tourist attractions of a new perspective in Samosir Island.
\end{abstract}

Keywords: Samosir Island; Lake Toba; burial container; megaliths; local tourism

\section{INTRODUCTION}

Tourism in Sumatera Utara Province is very well known. Some of the famous destinations as a mainstay are Nias Island and Samosir Island. Both areas have archaeological remains of the megalithic tradition, which are also used to develop national strategic areas as tourism mainstay. Samosir Island is not only known for its cultural tourism but also as a geopark. These tourist objects also require support through the development of crafts, arts and music, architecture, religion, way of life, traditional food, traditional clothing, regional languages, and local history as tourist attractions (Ardika, 2003: 4956).

Nias Island, located on the West coast of Sumatra Island, has a distinctive culture related to megalithic traditions. The settlement pattern here tends to be in flat hilly areas, generally consists of two rows of residential houses facing each other. Various stone relics from the megalithic tradition, well known as the ancient stone craft, are placed in front of the traditional house to symbolize the residents' social status. There are water tourism activities in Nias Island, a world-class water surfing competition listed in the national tourism activity calendar every year.

Samosir Island, as a geographical unit surrounded by Lake Toba, has its characteristics in archaeological remains. Various prehistoric relics, especially megaliths, are the dominant heritage in this region. The most prominent remains include a stone tomb or sarcophagus, stone jars, stone chairs, and tables. These relics' existence proves the development of a culture with its character and distinguishes it from other similar cultures to become its main attraction. Based on the actual culture in Samosir Island, it is not from its ancient culture as the tourist attractions. Current culture, especially regarding decorative arts, shows its very complex character. In one aspect, decorative arts still show original prehistoric characters with distinctive motifs or figures. Prehistoric 


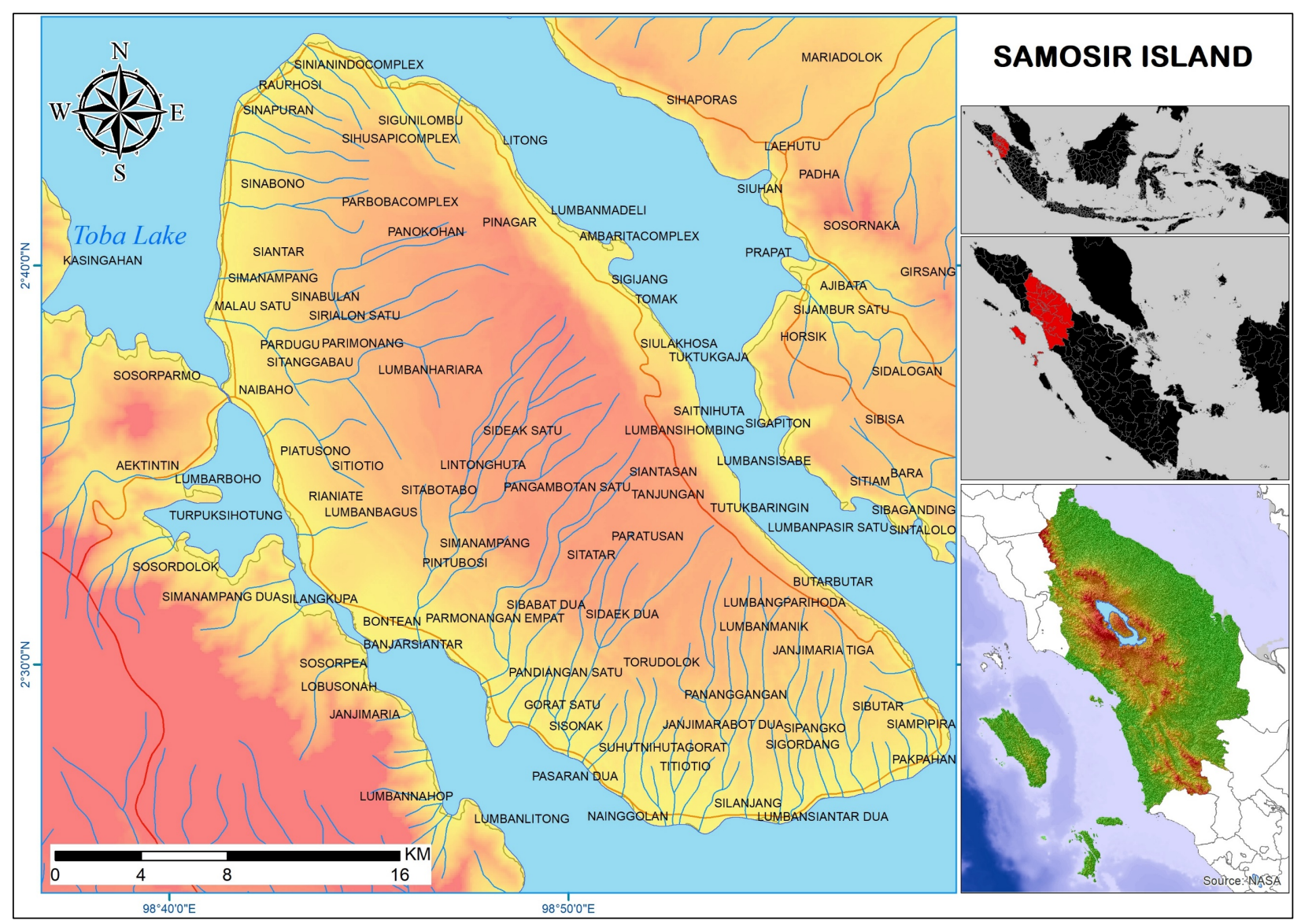

Figure 1. Map of Samosir Island Location

(Source: ArcGIS Database, 2019)

figures such as geometric ornaments, namely tumpal motifs or row of (isosceles) triangles, rectangle, rhombus, sphere, and tendrils motifs, as well as sculptures of frightening figures or known as monsters (Wiradnyana, Koestoro, Setiawan, Siahaan, \& Purnawibowo, 2016).

Samosir Island, with many remains of megalithic traditions, making the development of the area not only be environmentally based but also religiously based. Of course, people's daily lives are significant to increase objects' potential, considering that all religious activities in this area are based on past values that come from the Megalithic culture (Sztompka, 2010: 69-70). Local history shows that geological and archeological aspects are vital information used in tourism development efforts on Samosir Island and its surroundings. Starting with Mount Toba's eruption around 74,000 years ago (Pratomo, 2014: 30-31), which destroyed a part of life until the beginning of the early communities and becoming the Toba Batak people today. Often various historical relics around the area become information that is not well summarized. Various historical remains around this area are often poorly summarized information. This happens because information delivery is limited and does not touch all aspects of people's lives. In this regard, the information obtained for tourism was mixed between scientific and those that are not. In certain aspects, tourists often need information in the form of folklore, but with additional information, a historical object will be more attractive to tourists in understanding the culture of the local community.

Samosir Island in Lake Toba is the leading tourism driver of the economy. Cultural heritage and cultural identity in this region are a source of tourism wealth, so that the entire community should help ensure its preservation (Picard, 2006: 167). Therefore, tourism can be used as an instrument for regional development through object protection, cultural research, and research results to support tourism objects (UU RI, No. 11/2010). It is also necessary to develop the number of tourist destinations for archaeological objects to provide economic benefits for local communities, impacting the Indonesian people (Wiradnyana, 2019: 34-46). In this regard, it is imperative to build a tourism concept on the potential and character of the Samosir Island area with the background of the Toba Batak community.

Besides having a particular form and function, an archaeological object also records various other social aspects of people's lives. In this regard, an archaeological object is a symbol of the Toba Batak people's life in the past and even today. So, the archaeological remains are a symbol of the Toba Batak community. Geertz (1973) considers that symbols communicate meaning about someone or something (Abdullah, 2006: 240-241). This means that the archaeological remains illustrate various 
aspects concerning the human being, including the environment. Symbols have meanings linked in myths and operationalized in other cultural elements so that they gradually become part of these other cultural elements. This means that the same symbol can be used both in a political context and in a religious or economic context (Geertz, 1995: 102). Based on the background of the concept of material culture described above, an archaeological object can cover various social aspects of the Toba Batak community on Samosir Island. The breadth of the meaning behind the archaeological object is a fundamental asset to tourism information. Efforts to maintain local character in a tourist attraction are efforts to organize the community and others through local knowledge to ensure the sustainability of a tourist attraction in the region (Wiradnyana, 2018: 29).

Some of the archaeological remains on Samosir Island are not well preserved and even lack scientific information to describe the people's culture. Therefore, several tourism objects developed by specific communities arranged like real archaeological sites but faked objects. The concept of object forgery is less relevant for developing tourism in Samosir Island and its surroundings. This illustrates that the concept of developing a tourist attraction on an archaeological object is not clear. The problems described concern the form and information behind the archaeological object. This research tries to offer an ideal tourism concept for the Samosir Island area. This discussion's objectives include understanding that scientific information is very important in tourist attraction information, given the aspects that are of interest to tourists, such as aspects of value, the meaning of people's lives behind the tourist attraction itself. In line with that, this study discusses developing tourism objects with local characteristics. to develop a tourism object development concept with local character. The discussion's scope is archaeological objects related to the development of tourism objects on Samosir Island, Samosir Regency, Sumatera Utara Province.

\section{MethodS}

The method used in this research is a qualitative analysis method. This method describes many archaeological relics on Samosir Island to reveal the various aspects of them. The literature study and comparison method are applied by comparing the objects described with objects on similar sites in other places. From this inductive reasoning, various qualitative data can be interpreted to get meaning for an archaeological relic. The knowledge of archaeological characters and objects obtained is then developed into the concept of ideal and sustainable tourism development practices.

\section{RESULT AND DISCUSSION \\ The Background of Batak Toba People}

In folklore, it is mentioning that Siraja Batak descended from the sky to the top of Pusuk Buhit and then settled in Sianjur Mula-Mula. It then spread to the outskirts of Sumatra Island, which is still on the coast of Lake Toba (to Ulu Darat) to then spread on Samosir Island, and some of it spread to various mountainous areas of Sumatera Utara. In the past, the Batak Toba people lived in organizations with their own set of norms, often called adat, patik, and uhum. They live in one particular area and have a common goal. The Toba Batak ethnic groups generally live in rural areas. Among the Batak Toba people, there is an understanding that means to state territorial unity in the countryside, including Huta, Lumban, and Sosor. Huta is usually a territorial unit inhabited by families from one clan, while Lumban means an area inhabited by family members of one part of the clan. Sosor is an area inhabited by families descendants of the founders of the Huta territory (Simanjuntak, 2006: 163-165).

\section{Archaeological Objects in Samosir Island}

Lake Toba and Samosir Island formed in the eruption of Mount Toba in the Tertiary and Quaternary Periods around 74,000 years ago by throwing around 5,000$2,000 \mathrm{~km}^{3}$ of the earth's bowels then formed the plains in Batak Land. After erupting, the volcano partially formed a deep niche which is now Lake Toba. Then the second eruption occurred about 30,000 years ago. From the middle of Lake Toba appeared a new volcano. After erupting was divided into two parts, the part to the West became Samosir Island, and the part to the East became two plateaux, including Porsea Plateau and Parapat Plateau. Mount Toba's repeated eruptions spewed various types of rocks, including andesite, sandstone, and liparitic rocks (Van Bemmelen, 1970: 125). In general, geologically, it is formed from volcanic rock, which is dominating by tuff. The local community uses the tuff rock as raw material for making archaeological relics such as stone statues, sarcophagi, and other burial containers as part of Mount Toba's activities.

The fertile areas and used as agricultural areas are located in narrow valleys to the edge of the lake so that settlements tend to be in these fertile areas. On the inside of the island, settlements are much less common, tend to be random patterns and follow valleys or productive land conditions. Therefore, archaeological remains distribution tends to be around Lake Toba's shores, where the settlements are located. The people of Batak Toba initially embraced animism and dynamism. They believe in a power beyond the power within the human body that can affect the living lives. Besides, they also 


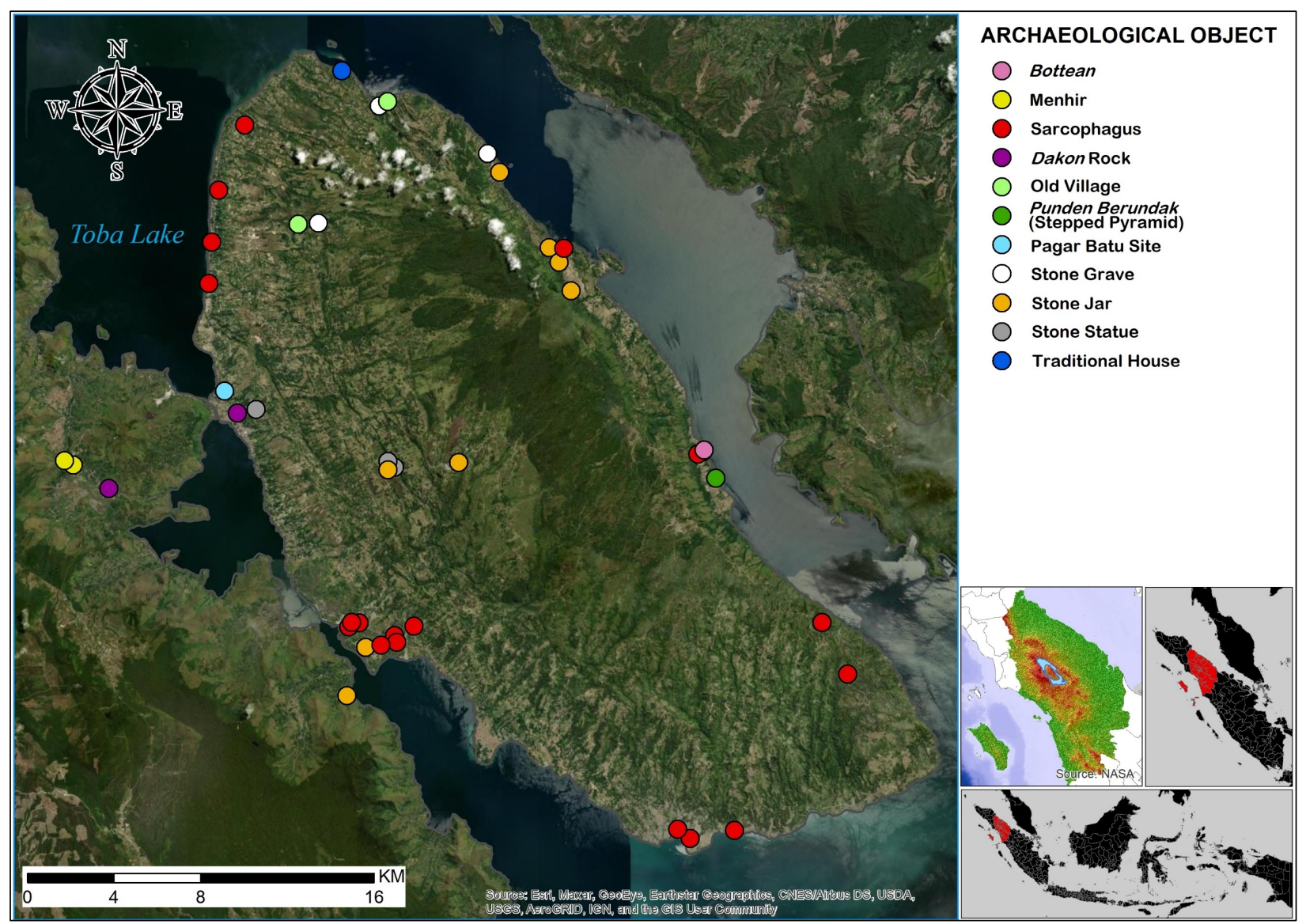

Figure 2. Distribution of archaeological remains in Samosir Island

(Source: Balai Arkeologi Sumatera Utara, 2016, map source from World Imagery by ESRI, 2020)

believe that this power resides in large stones, large trees. According to the Toba Batak community's belief, when a person dies, the spirit goes to the upper realm and gathers with their ancestors. Meeting the dead's spirit with their ancestors is a vital part of the old religion, so the procession of death is carried out with joy. This death procession takes place happily when the dead person's tasks in this world have been completed perfectly, among which all of his children have been married. The Toba Batak community adheres to a patrilineal concept. The death meeting with their ancestors is more focused on maintaining their genealogy based on male groups. The religious aspect that emerges and is very important includes respect for ancestors. In this regard, it is not surprising that almost all burial container on Samosir Island are related to their function as burial container for men.

Batak Toba's people have always known three burial types: primary, secondary, and primary-secondary burials. Primary burial is buried directly in the ground, either using a burial container or not. Secondary burial, which is preceded by carrying out primary burial, then the bones of the dead are removed from the ground (mangokal holi) and transferred to the burial container. Primary-secondary burial is a burial that simultaneously implements both (Wiradnyana, 2017: 43). Burial types are still carried out today by some of the Toba Batak people. Currently, the container used for primarysecondary burial processions is called tambak.

\section{Sarcophagus}

It is a rectangular grave, generally shaped like a boat with tapered ends and a curved center. It was used as a primary burial and later used as a communal burial vessel.

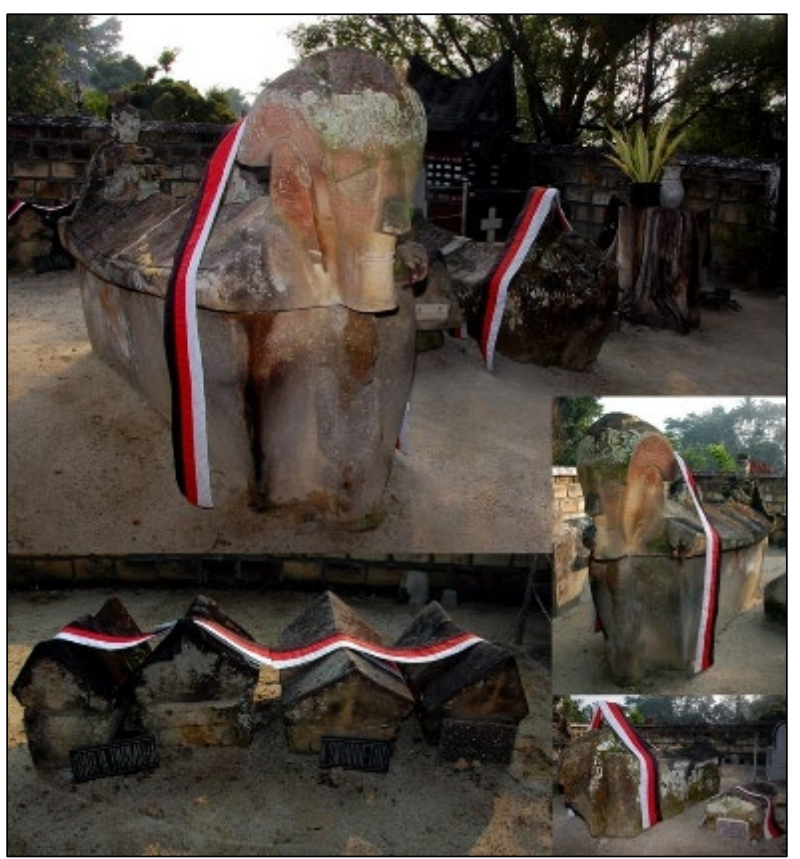

Figure 3. Sarcophagus

(Source: Balai Arkeologi Sumatera Utara, 2016) 
The shape is like a boat intended as a vehicle for the spirit to the spirit realm. Engraved human head (monster) are often attached to the burial container (monolith), and some are attached to the lid.

\section{Stone Jar}

This large jar-shaped burial container is generally not decorated. Some of the jars found were decorated with anthropomorphic, semicircular (fish scales) and tendrils. The hole size, which is about half a meter, indicates its function as a secondary burial for an individual only.

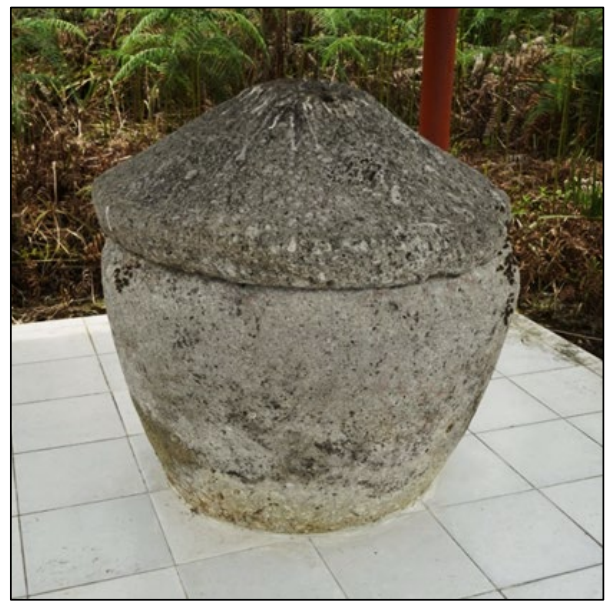

Figure 4. Stone Jar

(Source: Balai Arkeologi Sumatera Utara, 2016)

\section{Stone Box/Stone Grave Crate}

This stone burial container is shaped like a chest box, a square with approximately the same length and width measurement. In some cases, the height sometimes exceeds the length or width. A square-shaped burial hole is used to place the bones of the deceased after secondary burial.

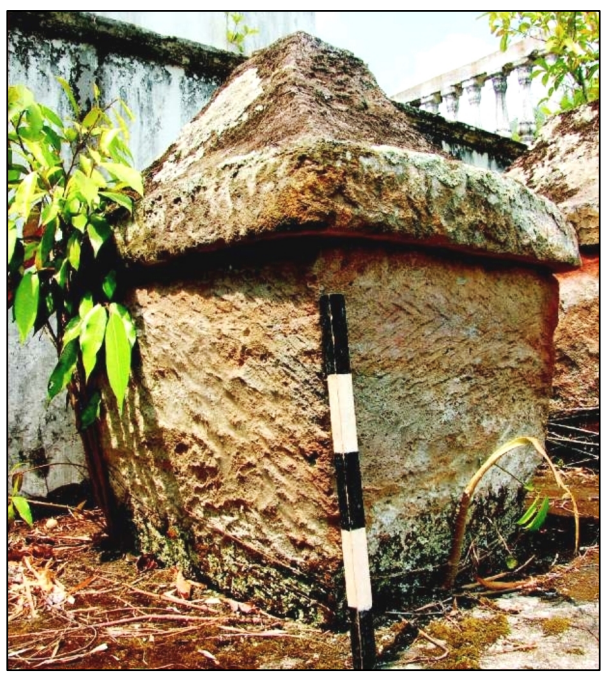

Figure 5. Stone Box in

(Source: Balai Arkeologi Sumatera Utara, 2016)

\section{Stone Chisel Grave}

The burial container carves a square burial hole in a large stone block (insitu). At the top, there pyramidshaped cover like the shape of the house roof.

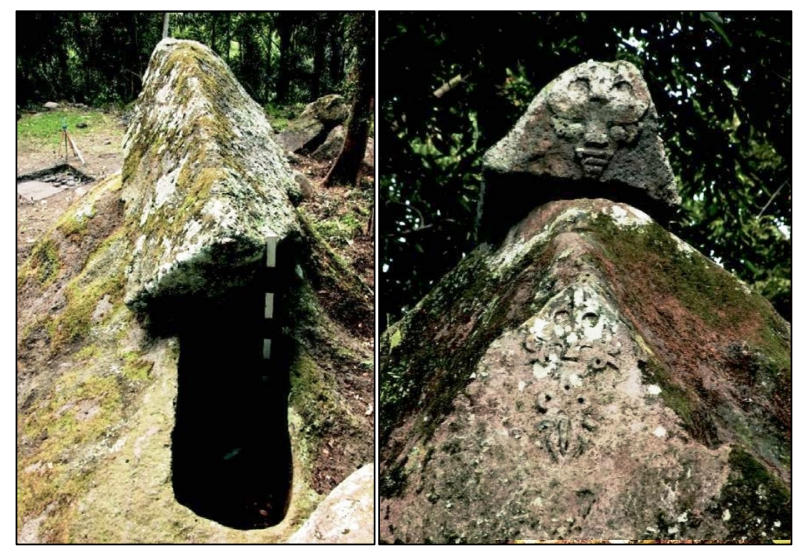

Figure 6. Stone Chisel Grave

(Source: Balai Arkeologi Sumatera Utara, 2016)

\section{Tambak}

It is a new primary-secondary burial container. This container varies in shape, with varying numbers of burial pits, and are communal burial containers.

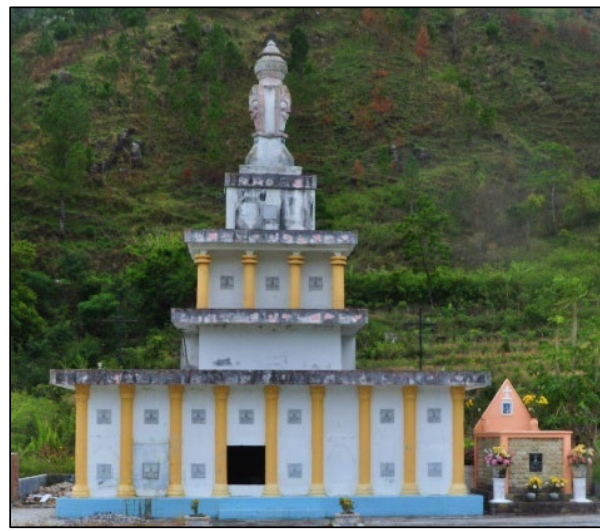

Figure 7. Tambak

(Source: Balai Arkeologi Sumatera Utara, 2016)

\section{Dakon Rock}

In several locations, people call this Parlobukan rock. Dakon rock on Samosir Island found in Simanindo and Pangururan Districts. There are several holes on its surface. This rock is used as a game board, played with a small pebble stone placed in the hole and moving one by one until it runs out alternately.

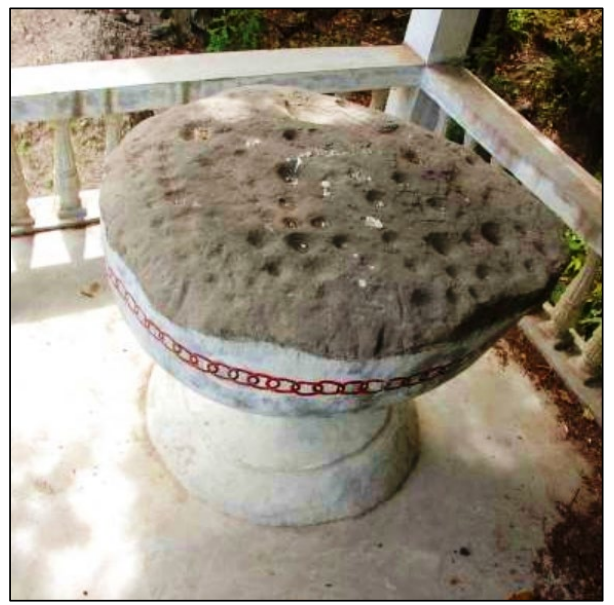

Figure 8. Dakon rock

(Source: Balai Arkeologi Sumatera Utara, 2016) 


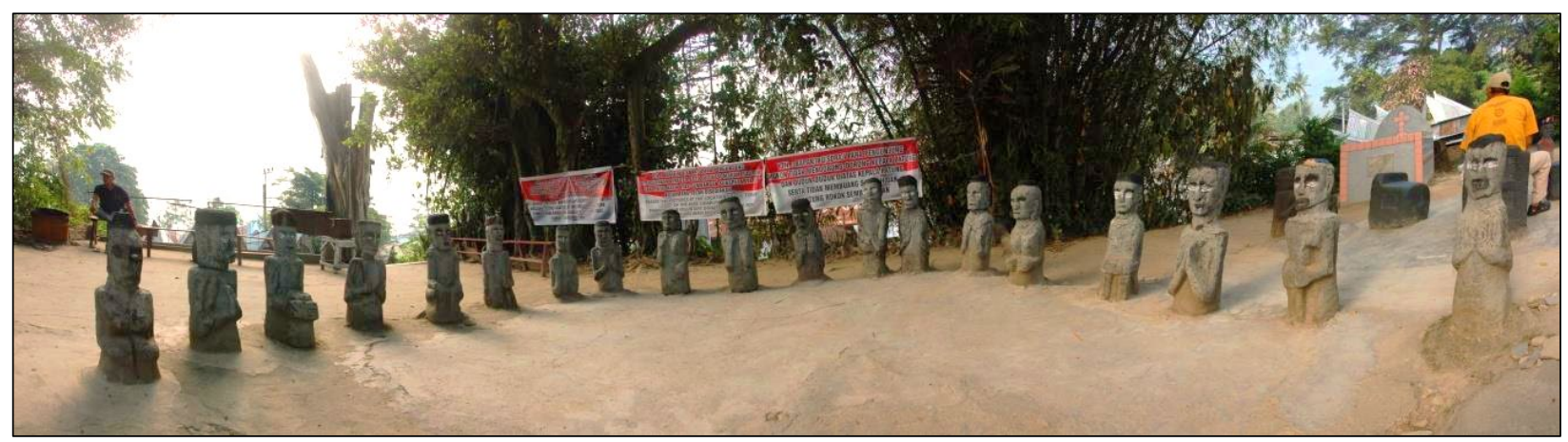

Figure 9. Stone Statues

(Source: Balai Arkeologi Sumatera Utara, 2016)

\section{Stone statue}

In general, this statue is a Panghulubalang Statue which functions as a protector from enemies or evil spirits and plant pests. Another function of Panghulubalang is associated with the embodiment of ancestors. The Batak Toba people's old belief that the Panghulubalang Statue functions if it has gone through a ceremonial procession by giving fertilizer in the form of oil or human ashes to the body's holes of the statue.

\section{Menhir}

In Pagarbolak Village, Pardomuan, Simanindo subdistrict, there are menhirs, and local people call them jonjong rock. This large menhir is related to the Megalithic Site of punden berundak (stepped pyramid), usually called Pagaran Batu. Menhir can also be in the form of borotan, which functions as a mooring for sacrificial animals in the procession of death. Besides, it can also be a tunggal panaluan, a wooden stick that is often used as a stick for shamans.

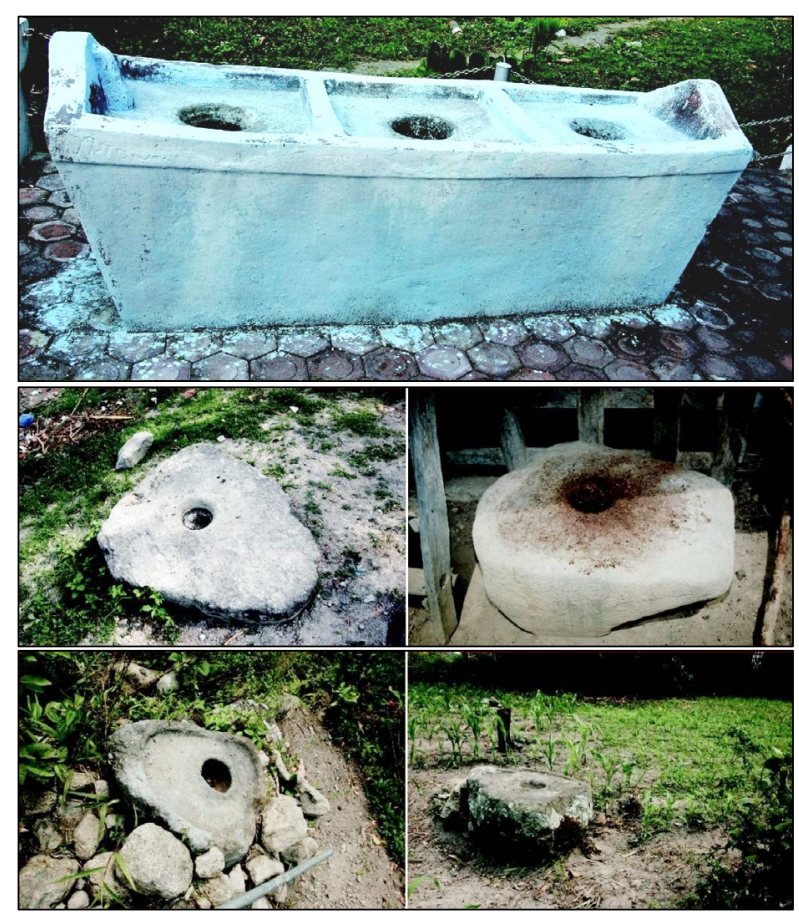

Figure 10. Stone Mortar (Source: Balai Arkeologi Sumatera Utara, 2016)

\section{Stone Mortar}

The shape and function of these stone mortars vary. Related to the animism concept, rice mortar is related to the belief that rice has tondi (spirit), so rice must be adequately treated. This is related to seams at the edges of the surface or around the mortar holes. The practical aspect of the seam is an effort so that the crushed material does not spill. The shape of a mortar such as a boat and engraved human face is related to religious meaning, whether related to the manufacture of medicines or potions.

\section{Bottean}

This object is in the form of an oval-shaped engraved monolith with a tapered top and placed historically from one another; Bottean functions as a mooring the solu (canoe).

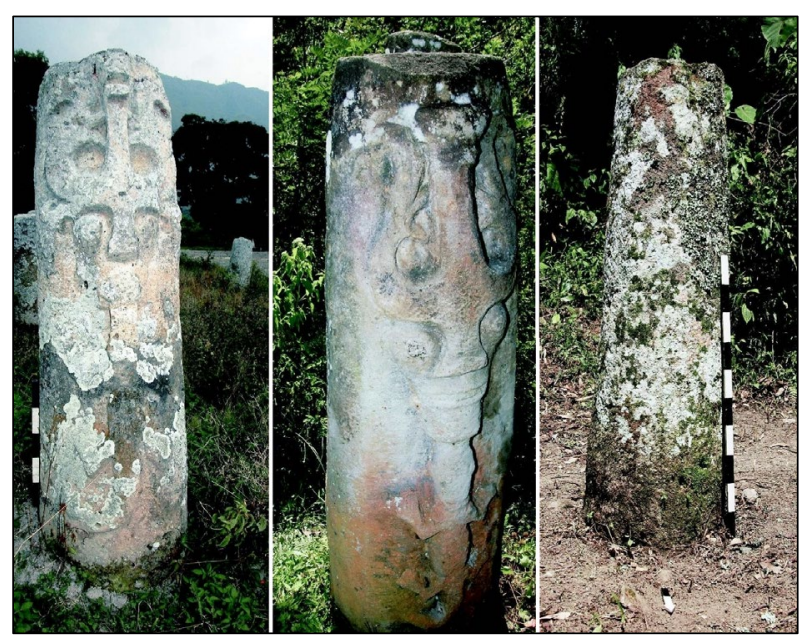

Figure 11. Bottean

(Source: Balai Arkeologi Sumatera Utara, 2016)

\section{Old Village}

Many ancient settlements are still found in the Samosir Regency area. Some of the villages are still inhabited today, and some have abandoned. An ancient village's characteristic is that it has a wall around the shape of a square or a square made of soil, and there are often bamboo trees on top of it. Inside the wall, there are several houses arranged in two rows facing each other. The first row is a residence, and the front row is a sopo (smaller house) to store agricultural tools or products. 


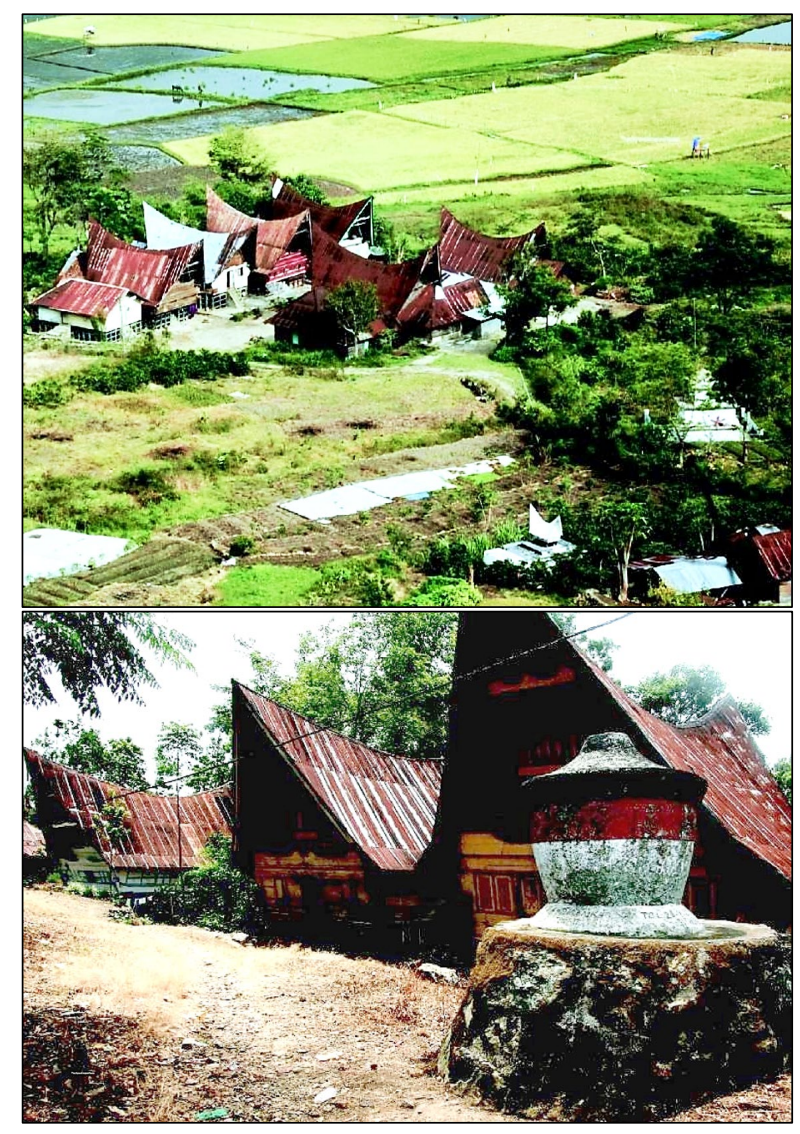

Figure 12. Old Village landscape

(Source: Balai Arkeologi Sumatera Utara, 2016)

\section{Traditional Houses and Decorative Patterns}

In the traditional Batak Toba house with stilt house architecture, the roof tends to be curved like the sarcophagus lid's shape. The house roof concept as the curved lid of the sarcophagus is identified as a boat's shape. Such a shape is reminiscent of the traditional house shape in the Dong Son culture, which is the architecture using a stilt house with a curved roof.

\section{Pagar Batu (Stone Fence) Site}

This site is located in Pardomuan Village, Simanindo District, about $9 \mathrm{~km}$ from Tomok Hutment. This site is a punden berundak (stepped pyramid) with four steps. Each step is bounded by a stone fence arranged around the area in a circular position. At the top of the page, the steps tend to be square. There are also stone chisel graves, stone mortar with five holes, one-hole stone mortar, stone sculpture, house, and around it, there is a bottean.

\section{Understanding of Archaeological Objects}

Samosir Island, with a settlement on it, is a mountain that is still active today. Several eruptions of Mount Toba formed this island until form a crater, namely Lake Toba. The most violent eruption took place around 74,000 years ago, which covered part of the earth's surface and changed world civilization (Pratomo, 2014: 30-31). Evidence of the earth's bedrock resulting from the eruption can still be observed in most of the areas around Lake Toba and parts of geological tourism objects. The eruption was also accompanied by the gradual emergence of Mount Toba's peak, rising above Lake Toba's water surface around 3,000 years ago. Before that time, Samosir Island could not be inhabited because it was still muddy and could only be inhabited several thousand years later (oral information from Pratomo, 2014). So, the geological process made the initial occupancy outside Samosir Island. This is reinforced by Si Raja Batak's folklore, which has descended from the top of Pusuk Buhit and lived in Sianjur Mula-Mula. Mount Pusuk Buhit and the Sianjur Mula-Mula area are outside Samosir Island or still on the island of Sumatra. So, the settlement on Samosir Island originated from Sianjur Mula-Mula, and in folklore, it is said that it spread to Samosir Island. This confirmed that Samosir Island could only be inhabited several thousand years later after rising from the surface of Lake Toba's water. Schnitger (1939) stated that the Batak Toba culture's development with the megalithic tradition's characteristics on Samosir Island only started at least about 1,000 years ago (Heekeren, 1958: 78; Wiradnyana et al., 2016: 99). The megalithic tradition with the concept of worshiping spirits (especially ancestral spirits) is a tradition with a universal character, considering that almost all world regions experience and know this culture.

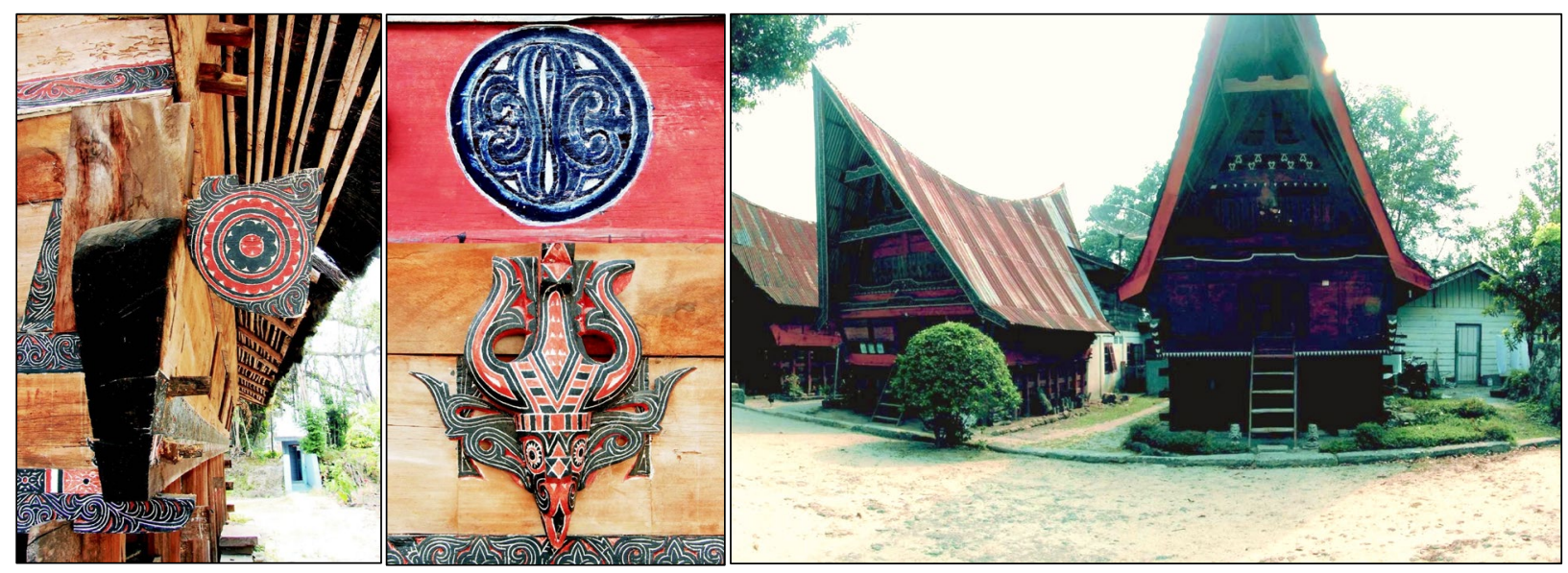

Figure 13. Decorative Patterns and Traditional Houses (Source: Balai Arkeologi Sumatera Utara, 2016) 


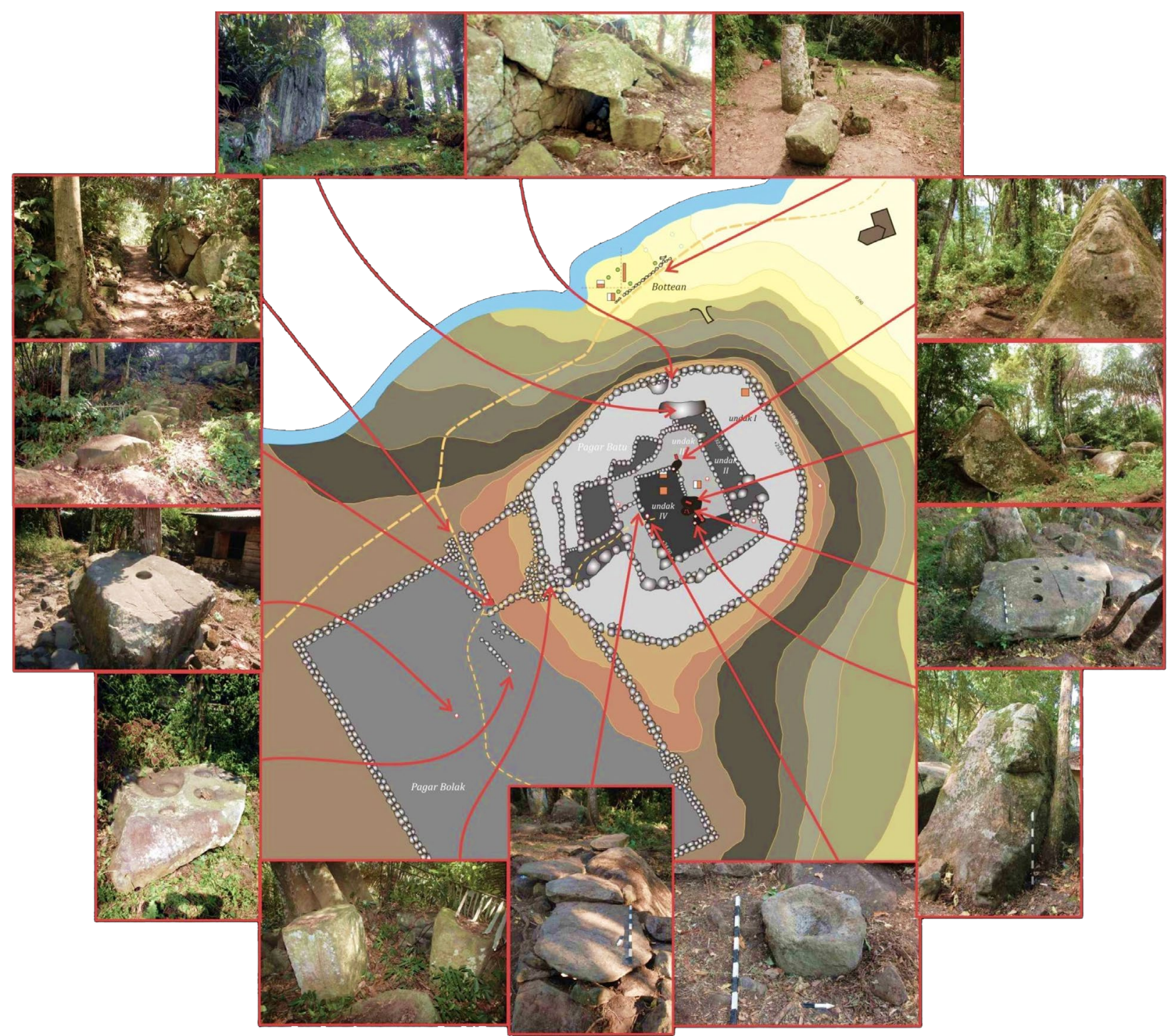

Figure 14. Pagar Batu Site Plan area

(Source: Balai Arkeologi Sumatera Utara, 2016)

In the early 19th century, European began to pay attention to various aspects of cultural heritage made from large stones known as megalithic culture. Various forms of building with stone materials/constructions are found very widely in European countries and studied up to the Asian region. In Indonesia, megalithic culture is related to megalithic culture in Melanesia and Polynesia. Indonesia is considered the link in the chain from West to Pacific about solar worship (Perry, 1918: 3; Sutaba, 2001: 1-4). Other experts argue that Austronesian speakers carried the megalithic culture in two major waves: the old megalithic and the young megalithic tradition. The old megalithic tradition produces dolmen, menhirs, stone, and thrones. The young megalithic tradition produces sarcophagi, stone graves, and ancestors' statues (Poesponegoro \& Notosusanto, 1984: 205-208; Sutaba, 2001: 5).

The basic concept of megalithic culture is respect for ancestral spirits so that all buildings have a connection with ancestral spirits. Besides, there are also aspects of agriculture and primary-secondary burial (Soejono,
1989: 221-231, 2008: 5). Otherwise, there is a belief that the ancestors' spirits have magical powers and reside on the top of a mountain or hill (Sutaba, 2001: 16). However, not all Megalithic buildings are related to ancestral spirits, and some are related to certain spirits that are not related to ancestral spirits. Megalithic buildings related to social aspects, such as symbols, carried out certain ceremonial processions or raised social status (Wiradnyana, 2015: 90) or certain spirits' media presence. There are megalithic buildings in a vertical position, and some are also formed in a horizontal position. The entire building has a different function. The raw material for megalithic buildings is generally stone. However, some are made of wood, such as cathodes in East Sumba or statues' embodiments in Batak Toba, Batak Karo, and Nias. The existence of megalithic buildings marks the surrounding dwellings.

During its development, the megalithic tradition can still be found today in several regions in Sumatera Utara. Mangokal holi and tambak are a form of development of the megalithic culture, specifically, secondary burial and 
sarcophagus burial containers. Likewise, the shape of Megalithic buildings in vertical and horizontal positions is often associated with male and female symbols and, at the same time, as a warning sign for men and women. Besides, its development is also related to social aspects, such as social status and practical functions. In carrying out the megalithic tradition, the community no longer recognizes the concept behind the tradition. Many people considered the traditions are more an effort to improve social status in the community. The Megalithic buildings often functioned only with practical aspects, such as tourism objects.

In Samosir Island, Sumatera Utara, the megalithic tradition has quite a lot of variations. The existence of this tradition indicates the existence of a megalithic Austronesian migration. The most prominent aspect of the megalithic tradition in Samosir Island is the procession of death. The forms of burial containers and their processions in the Batak Toba people or the surrounding community also have the megalithic tradition's characteristics with the shape of a similar burial container. Likewise, with the burial procession, which is still carrying out primary burial followed by secondary burial procession. At present, there are tambak buildings that function as primary-secondary burial containers, which are known in the Malim belief, which is the old beliefs of the Batak ancestors (Gultom, 2010: 81). In prehistoric culture on the coast, secondary burial was also known using clay jars. In Samosir Island, burial traditions with jars were made from stone. This reflects the adaptation of the Batak Toba community in utilizing the abundant raw materials around it. The burial tradition with jars is one of Dong Son culture's characteristics. Various cultural objects were made of bronze or body decorative pattern motifs and traditional houses thick with the Dong Son culture.

In Indonesia, the burial tradition using jars was widespread after the first millennium AD. Burial activities with jars at the Lolo Gedang site, Kerinci Region, Jambi Province, and surrounding sites are estimated to be around the 11th to 14th centuries (Bonat, 2015: 35; Budisantosa, 2011: 89-90). The existence of animal carvings such as elephants and various other ornaments in the Batak Toba has similarities with the Dong Son culture. However, in the Indo-Malaysian Islands, especially in Nias and Tabon, the burial tradition with jars had taken place at the end of the second millennium and the beginning of the first millennium BC brought by Cham settlers (Bellwood, 2000: 393). Otherwise, this megalithic tradition may have taken place in Indonesia in this period, but there is no sufficient data evidence collected so far. Megalithic traditions that are still ongoing today are also found in Kalimantan, Sulawesi, Sumba, Bali, Java, and other areas.
In Samosir Island, the village is part of the megalithic tradition. The residential system facing an open space or courtyard in the middle is reminiscent of the water or river community residential model where housing is located on both sides of the river. It is just that the village in the Samosir Island area is bordered by an earthen wall with bamboo plants on it and an entrance and exit to the village. The perimeter wall is usually made from a pile of soil mixed with stones or from stone structures. At the village entrance, the walls are usually covered with stones deliberately shaped into a square to give a solid and neat impression. One example of a unique village and somewhat different from the village in general on Samosir Island is the Pagar Batu site. At the top of the punden berundak (stepped pyramid), there are remains of old buildings and stone chisel graves. The wall around the punden is formed from a stone arrangement by adjusting the environmental conditions to be often not symmetrical or regular. In a Batak Toba village, familiar cultural objects are the presence of a perimeter parik (wall), traditional houses, and the existence of stone mortars, as well as burial containers. The three cultural objects show the inherent concept of the life goals of the Toba Batak community, namely hasangapon (honor), hagabeon (many descendants), and haromaon (property/wealth). The existence of these cultural objects reflects aspects of religion, agriculture, and law. However, it seems that the aspect of life in a dwelling is also adaptation, which plays a vital role in the community's life.

In general, the traditional house is in the form of a house on stilts. This traditional house has a curved roof like a boat's profile with the rear end higher than the front end. Bottean is part of the foundation pillar of a traditional house which also functions as a boat tie pole. Customary houses are often located outside the walls of the village but become part of a village. Bottean, located in Parmonangan Village, is located not too far from the Pagar Batu Site, so it is part of the Pagar Batu Village. The Bottean has an average height of about 1.5 meters, and two of them are located at the front, decorated with carvings of gajah dompak (elephants).

The traditional house is also symbolized as part of the transportation. It was known to the Batak Toba people when they migrated to this area. The decorative patterns in the Batak Toba traditional house depict various kinds of animals and vines. Some of the ornaments found in tassels, like long feathers, whether on flora or fauna carvings, are reminiscent of similar designs on bronze objects from Dong Son. Carvings of lizards or lizards in front of traditional houses are related to aspects of honesty or truth which are constantly reminded of the village leaders. Animals that are the objects of sculpture are usually known as flora and fauna and live around 
their environment. Some are described as naturalists in their development, and some are stylized but did not leave their original form (Wiradnyana et al., 2016: 86).

The sarcophagus is a form of burial container on Samosir Island, found almost around Samosir Island. Its profile which resembles a traditional house, which is in the form of a boat, makes this burial container identified as a vehicle for spirits to another world. The monster carving on the front of the sarcophagus is believed as a repellent. The repellent aims to safeguard the spirits did not experience interference on their way to the spirit world. There are other carvings, both in front of the container and behind the sarcophagus' lid. The carvings depict people who have a close relationship with the dead. The sarcophagus is usually placed in the direction of a high mountain or hill. Due to the transfer of the object to another location, it is often found that some are still oriented towards mountains, especially in the interior of Samosir, and on the coast, they are often directed to the lake. The sarcophagus that leads to the mountain is closely related to the megalithic belief that a mountain is a holy place where the spirits live, and the sarcophagus is deliberately directed to Mount Pusuk Buhit so that the spirit does not get lost on its way (Poesponegoro \& Notosusanto, 2009: 247-248). However, in the Palipi sub-district, the sarcophagus' orientation tends to turn its back on the lake and Mount Pusuk Buhit. It is indicated that it is oriented towards the area of origin or ancestral land, which probably the area around Balige Districts.

Stone jars, stone chisel graves, and stone crate graves tend to have small holes (burial container) so that they are not possible to be used as primary burial container. The stone jar made it more likely for a second or secondary burial. This is supported by the fact that a jar can contain the bones of more than one individual. Stone jars are generally made of tuff and sandstone and buried in the ground. Meanwhile, the stone cube box or stone grave crate and stone chisel grave tend to be made by sculpting a monolith, and the size of the tomb container is small so that it is used as a secondary burial container. Stone cubes tend to be smaller in size than the stone chisel graves, so it is also possible for the stone chisel graves to be used as the primary burial container. Stone chisel graves are usually made by utilizing the presence of large rocks around them. These graves are reminiscent of rock cliff burials in Toraja and the interior of Kalimantan but usually on vertical cliffs that are difficult to reach. Such stone chisel graves can also be compared to the Umang cave in Sarinembah Village, Munte District in Sembahe Village, Sibolangit District, Deli Serdang Regency, and many known to the Karo people. Gua Umang (kind of niche) was made by engraved a rock or cliff wall to produce a space that became a burial container. Stonewall graves do not always function as individual burial container, but some also function as communal burial container (Wiradnyana et al., 2016: 71).

The entire burial container in Samosir Island is part of the megalithic tradition, both primary and secondary burial processes. During its development, the burial containers were made in various shapes. Some were in the form of a stone cube with relatively large and multilevel size. Also, some were made by placing a sarcophagus or stone jar on top of a square building. They have various decorations and used as a container for communal or family graves until now. The burial container is called tambak, a local term for a new burial container, which is the old burial container's development. Megalithic relics called borotan are menhirs used to tie buffalo to be slaughtered in traditional ceremonies such as funerals, saurmatua, and mangongkal holi. Borotan or menhirs are also part of the procession as a symbol of the ancestors' presence during the deliberation. The ancestors have known the agreement of a deliberation. Borotan or menhir is also a medium for ancestors' presence, a symbol of ancestral existence, and a link between the Upper World, Middle World, and the Underworld to bring balance and prosperity (Wiradnyana, 2017: 46).

The stone mortars on Samosir Island vary in shape, some are very neatly made, and some are made only of monolithic stone by making holes and seams around them. Its function is also adapted to the shape. In general, stone mortar functions in agriculture. Nevertheless, there are also related to medicine. Like a mortar in the shape of a boat, it functioned only for concocting drugs. This form and function are an attempt by the datu (shaman) to speed up the process of making medicines because the boat is a medium. It was considering that mixed medicine is partly believed to be based on the guidance of the spirit. Through mortar, the power given by the spirit will affect the medicine that is being made. The people believed that the datu have knowledge and wisdom for a system of counting, measuring, weighing, and others (Koentjaraningrat, 1990: 374-375). So, the stone mortar is a symbol of the interaction between spirits and datu. Therefore, the stone mortar is used as a medium for the spirit to provide the medicine's strength or efficacy being concocted. Also, as a medium for the datu to ask for the spirit's strength in making medicine. The mortar is also a symbol of social status. This is related to the process of establishing a village. A village is inhabited by a family that is one clan with a limited number of family heads. One of the family heads was the King or clan of King's descendants who cleared the land for the first time and owned the land. Agriculture is the primary source of income, and the King is usually the one who has a stone mortar. Stone mortar for the Batak Toba people and their culture has a strong relationship 
that underlies the existence of a nuclear family or kinship of one ancestor or clan in a huta.

\section{Tourism Development}

In the context of development, a tourism development concept is needed, based on the local area's conditions, not importing external elements that are brought to the area that is not part of its culture and environment (Manuaba, 2009: x). The existence of archaeological potential in Samosir Island should be built based on historical and old conceptions. The archaeological object must be linked to the community and traditions that are still being implemented. The objects on Samosir Island are monuments related to the geological process of Mount Toba's eruption and the people's activities and archaeological remains associated with the death. In this regard, various aspects of Lake Toba and Samosir Island's formation process are significant parts of being a tourist attraction or concept of back to nature, apart from people's lives with various meaning patterns. In line with this, the procession of death or something related to it becomes a tour package that should be developed-considering these three aspects worthy of being developed into local tourism on the island of Samosir and a specific cultural area (Koentjaraningrat, 1987: 128).

According to Harrison (2013), the public has a responsibility to preserve cultural heritage. The concept of salvage and preservation is the basis of public involvement, which intersects with the heritage existing in the present. The communities may have an artefactual object or historical building due to inheritance, grant, or access that allows them to bound by the past. As a heritage, the cultural heritage must be maintained so that it does not lose the power and can be passed on to future generations without diminishing its value (Surbakti, 2017). Many parties understand that preservation is an effort to direct the cultural heritage to 'not change' or 'restore it to its original state,' preservation carried out is only for the cultural heritage itself. This concept certainly cannot be applied to the old cultural heritage that has not been used by the community because it does not have a significant impact on the current system of society. Preservation of heritage can apply by maintaining its value while actualizing it into the context of the current system of society (Astiti, 2017). Astiti (2016) suggest that it is necessary to change the way to manage cultural heritage in the future, which is currently very 'top-down.' One of the ways is management by using a sustainable tourism approach through the concept of cultural tourism as a conservation tool. Sustainable tourism products are products that are operated in harmony with the local environment, society and culture so that people continue to be beneficiary rather than the victim of tourism development.

According to Ardiwidjaja (2019), culture is the one that utilizes sustainable tourism as a tool to strengthen conservation efforts. As a foundation for the development of sustainable tourism in the cultural heritage site area, it is necessary to pay attention to several issues that influence it. Sustainable tourism based on aspects of natural and cultural environment conservation, improving the quality of the community's life and economic empowerment of the local community. Some understanding of cultural tourism from experts related to cultural tourism activities of the people described through cultural heritage in the form of monuments, archaeological sites, and historical sites.

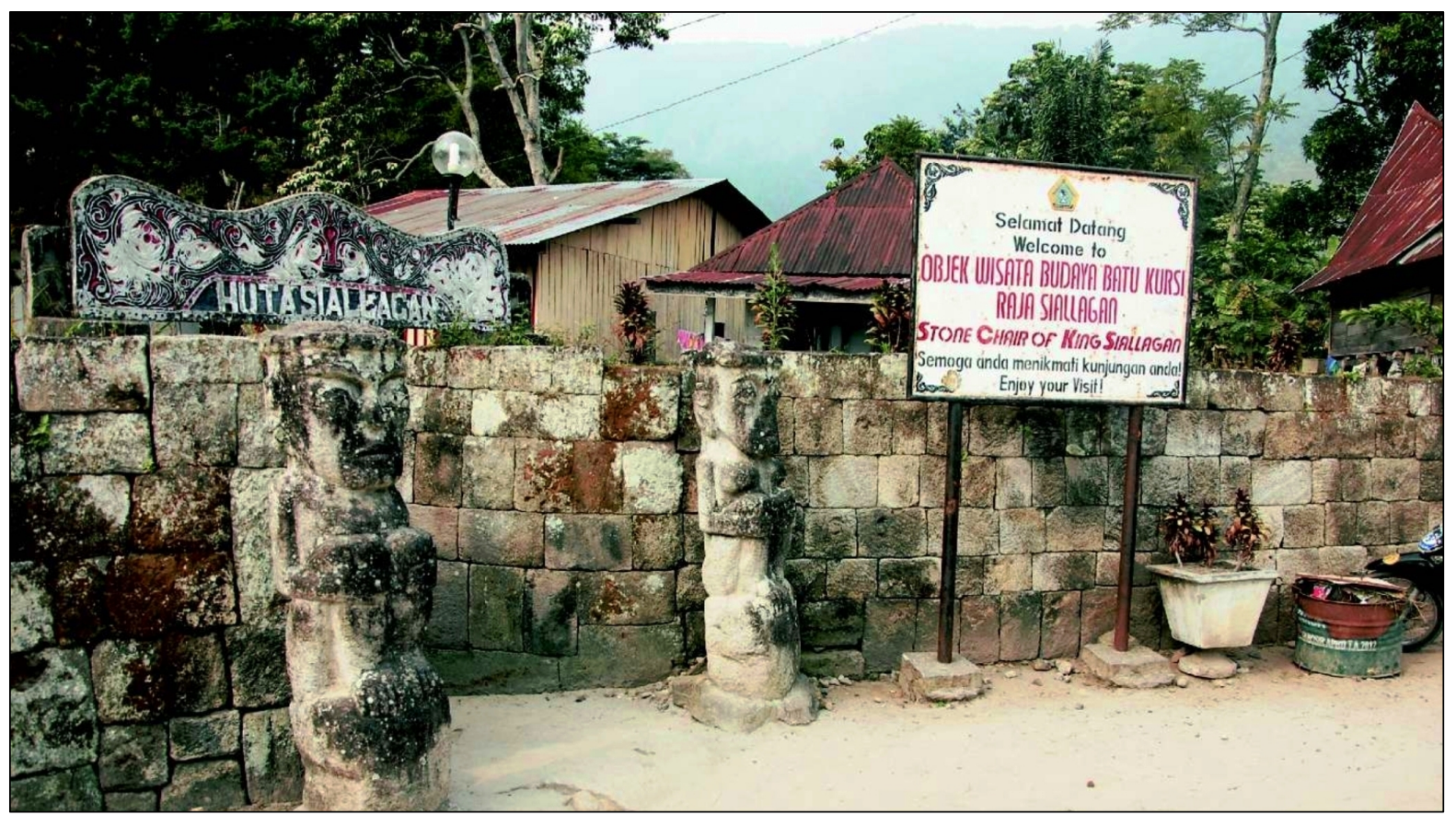

Figure 15. Cultural heritage site as a tourism object in Samosir Island

(Source: Wiradnyana \& Setiawan, 2013) 
Then the understanding related to a journey to increase appreciation and knowledge of cultural heritage, as well as understanding that related to the aspects of sociocultural life such as history, tradition, custom, language, and others (Ardiwidjaja, 2019: 33).

Meanwhile, in general, tourism development by prioritizing economic growth, ignoring environmental sustainability and the interests of local communities (Arida, 2009: 15), so that the concept of tourism becomes weak and profits will flow out of the region. Likewise, tourism managers on Samosir Island only rely on Lake Toba as their tour package. The concept related to the context becomes weak, and tour packages become less attractive and do not involve the local community. It would be nice if hotels on Samosir Island prepare tour packages relying on Lake Toba alone and cover all aspects of the environment and the people's lives. So thus, tourism in Samosir Island becomes basic in order to build local tourism. So, a tour package on Samosir Island is a system with its subsystems. As a system, it can be said that the tourism system on Samosir Island includes only Lake Toba, and its subsystem includes the geology of the rest of the Toba eruption, flora and fauna, people with active cultures, and archaeological relics. Therefore, all of these subsystems are inseparable parts of one another (Sztompka, 2010: 2).

Past cultural heritage such as Megalithic remains, for example, should be developed into an attractive tour package, considering that the conception is still ongoing and is very distinctive as a Batak Toba cultural character. It would be nice if hotels and tourism providers used it as part of a tourist attraction. Not only that, various people's lives with their traditions, with a pattern of meaning, become tourist objects that need to be packaged in such a way so that they become attractive and distinctive tourist objects. So, the environment, society, and archaeological remains become part of the tourist attraction on Samosir Island. This means that a tourist attraction must have a context because, without context with other things, it will become mere entertainment or an edited monument, which has a very shallow quality of performance and is not attractive. Besides, it avoids the concept of impression in which a community culture is seen as a pretense because impression begins with pretense, for example, the pretense in the implementation of rites (Kurnianingsih, 2008: 85). By exploring objects as a whole and holistically, the community will be directly involved and enjoy the results.

The development of environmental tourism can be related to the various information. One of the highlights is the eruption of Lake Toba and its objects, also the condition of its endemic flora and fauna. Also related to the people's wisdom is sustainable or used in connection with treatment. Community Life as a farmer is also an

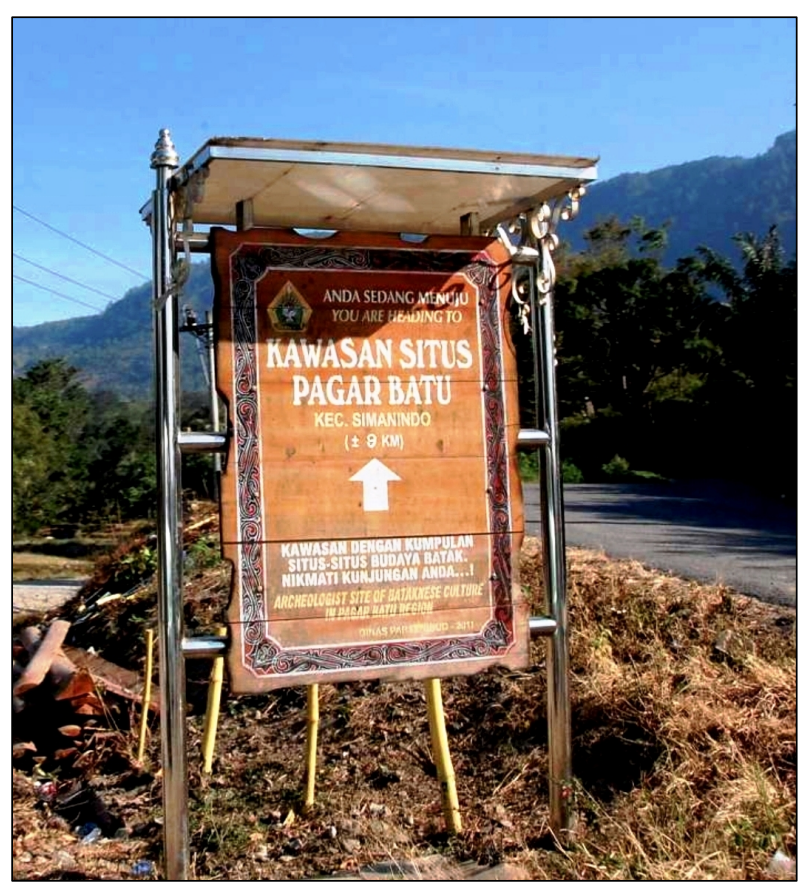

Figure 16. Archaeological Site as a tourism object in Samosir Island

(Source: Wiradnyana \& Setiawan, 2013)

enticing part to develop, both to irrigation management as an agricultural system or various ceremonies related to agriculture itself. Besides, various traditions related to entertainment alone are a significant part of developing the local community's wealth. The people of Batak Toba in Samosir Island are among the many communities that still sustain this tradition about the archaeological relics of the megalithic tradition. Especially about the conception of death. This will be very attractive to tourists, considering that the megalithic tradition is part of the Indonesian culture in general. So local tourists will be able to reflect on their past lives on the lives of the Batak Toba people. This is possible considering that the tradition is still deeply rooted in Indonesian society, especially the Toba Batak community. For local tourists, aspects that are understood only in the skin of the traditions can be known and enjoyed in performances or community life on Samosir Island.

The concept offered of tourism development in Samosir Island is an effort to build tourism with local wealth. With the developed local characteristics, tourism in Samosir Island will have unique characteristics. Of course, these characteristics will be more attractive to tourists who want to know about the Batak Toba culture in particular. With tourism that is based on localization, the most beneficiaries are the local communities (Arida, 2009: 2), both in the economic, social, and cultural context. Of course, this requires the Regional Government and regional tourism managers' commitment to being in line with the objectives to be achieved for tourism sustainability on Samosir Island. So, the ideal tour packages developed to the community's condition. The archaeological remains and 
environmental potential in Samosir Island include Ecotourism packages, which exploit Lake Toba's beauty, in line with the geological objects resulting from Mount Toba's eruption and its flora and endemic fauna. It also contains various local pearls of wisdom on environmental management, including how medicines were made from various flora in their environment. This tour package can also be divided into two: 1.) an environmental tour package that describes aspects of the Batak Toba community's agricultural life with various related processional activities and 2.) various other attractions in the community's social life. Other tour packages, such as the megalithic tour, include exploring the archaeological relics with mangokal holi tradition (the process of taking bones from a grave) and other aspects of the tradition related to death. So, tourism with the community as interaction by understanding how the community takes the object's initiative to be developed (Picard, 2006: 164).

The development of regional assets in the form of archaeological sites as tourism objects can be carried out considering that the assets in the form of sites can provide good information as an object. Information is limited to site units, but the information referred to can link between sites or between processions. This means that information can describe a site descriptively and provide the entire process that has been going on and its relationship with other sites and the processions that surround it. So that what is seen as people's behavior can be appropriately explained. The linkages between these sites can present a shared concept between regions to create linkages between sites. This concept is the idea of joint tourism in cross-regional tour packages but in one model, namely special interest tourism of historical attraction (Wiradnyana, 2019: 40). The tourism package is the local community's idea by taking over tourism activities and their benefits while adjusting their concepts and methods with local peculiarities (Picard, 2006: 163).

Of course, in tourism development involving local communities is not simply works. The main challenge is obtaining results that cannot be directly impacted economically so that various programs are planned to be hampered. For that, it is vital to empower the existing social system in the community, such as a local concept in the form of Dalihan na Tolu. This social system regulates the rights and obligations of the Batak Toba community. It consists of three elements, namely hulahula (the woman giving side), boru (the woman recipient side), and dongan tubu (one clan side) (Simanjuntak, 2015: 97). With this consensus, the community will be socially bound in various activities, especially concerning tourism development in the region. So, a tourist attraction on Samosir Island will be managed by the owner based on Daliha na Tolu's concept. The result is a tourist attraction built together with relatives to become the identity of a family. With this system, it is expected that there will be healthy competition in efforts to develop tourism objects on Samosir Island. In line with that, tourism pockets should also be formed to accommodate the outside community's various behaviors with their various cultures. Tourism activities will not be understood equally by all people so that the benefits will be different. It is necessary to exchange benefits, considering that the potential objects are also different in each area, so mutual support between regions is part of what must be done (Ritzer \& Smart, 2011: 281). This is necessary for maintaining the stability of the Batak Toba people's culture on Samosir Island in general due to the social and economic impacts that are built up from tourism itself.

\section{CONCluSION}

Many archaeological objects on Samosir Island is a legacy of the megalithic tradition. All of these relics are interrelated both in terms of their conception and function. So, an archaeological relic has a close relationship with other remains. The burial container is the most common monument found on Samosir Island. In this regard, burial is a very important procession, besides from the agricultural aspect. The availability of relevant information is an absolute must-have so that objects can be understood and engaging.

The development of regional assets in the form of archaeological sites as tourism objects is carried out considering that these assets can provide good information as an object. The tourism package built should be the local community's idea by being directly involved with tourism activities and getting the benefits while adjusting the concepts and methods with local peculiarities. By interconnecting the archaeological remains on Samosir Island, it is necessary to develop unique tourism and have a local character. The whole family is involved in developing their tourism through Dalihan na Tolu. So that the development of tourism on Samosir Island entirely involves the local community.

\section{ACKNOWLEDGEMENT}

We would like to thank some parties involved in this limited research, including the Batak Toba community in Samosir Island, the Kabupaten Toba Government, and the Balai Arkeologi Sumatera Utara. We also thank all members of the Kapata Arkeologi Editorial Boards to helped publish this research article. 


\section{REFERENCES}

Abdullah, I. (2006). Konstruksi dan Reproduksi Kebudayaan. Yogyakarta: Pustaka Pelajar.

ArcGIS Database. (2019). GEBCO 2019 Basemap (NOAA NCEI Visualization). Retrieved October 19, 2020, from ArcGIS Hub website: http:/hub.arcgis.com/datasets/

Ardika, I. G. (2003). Komponen Budaya Bali sebagai Daya Tarik Wisata. In I. G. Ardika (Ed.), Pariwisata Budaya Berkelanjutan. Refleksi dan Harapan di Tengah Perkembangan Global (pp. 49-56). Denpasar: Program Studi Magister (S2) Kajian Pariwisata Program Pascasarjana Universitas Udayana.

Ardiwidjaja, R. (2019). Preservation of World Heritage Sites Viewed from the Perspective of Sustainable Tourism Development. Kapata Arkeologi, 15(1), 25-34.

Arida, N. S. (2009). Meretas Ekowisata Bali, Proses Pengembangan, Partisipasi Lokal, dan Tantangan Ekowisata di Tiga Desa Kuno Bali. Denpasar: Udayana University Press.

Astiti, N. K. A. (2016). Sumber Daya Arkeologi dalam Pembangunan Pariwisata Berkelanjutan di Provinsi Maluku. Kapata Arkeologi, 12(1), 15-28.

Astiti, N. K. A. (2017). Kawasan Kompleks Bangunan Megalitik di Kabupaten Lahat sebagai Daya Tarik Wisata Budaya dan Alam. Kapata Arkeologi, 13(2), 195-208.

Bellwood, P. (2000). Prasejarah Kepulauan Indo-Malaysia (D A. Tanudirjo, Anggraeni, D. Witjaksono, \& Mahirta, Eds.). Jakarta: PT Gramedia Pustaka Utama.

Bonat, D. (2015). 4000 Tahun Jejak Permukaan Manusia Sumatera, Perspektif Arkeologis di Dataran Tinggi Pulau Sumatera. Medan: Unimed Press.

Budisantosa, T. M. (2011). Megalit dan Kubur Tempayan Dataran Tinggi Jambi: Situs Lolo Gedang, Kerinci. In Asia Tenggara dalam Persepektif Arkeologi. Palembang: Balai Arkeologi Palembang.

Geertz, C. (1973). The Interpretation of Cultures. New York: Basic Books.

Geertz, C. (1995). After the Fact: Two Countries, Four Decades, One Anthropologist, The Jerusalem-Harvard Lectures. Cambridge: Harvard University Press.

Gultom, I. (2010). Agama Malim di Tanah Batak. Jakarta: Bumi Aksara.

Harrison, R. (2013). Heritage Critical Approaches. London: Routledge.

Heekeren, H. R. van. (1958). The Bronze-Iron Age of Indonesia. S-Gravenhage: Martinus Nijhoff.

Koentjaraningrat, R. M. (1987). Sejarah Teori Antropologi I. Jakarta: Universitas Indonesia Press.

Koentjaraningrat, R. M. (1990). Pengantar Ilmu Antropologi. Jakarta: Rineka Cipta.

Kurnianingsih, A. (2008). Simulacra Bali: Ambiguitas Tradisionalisasi Orang Bali. Yogyakarta: Insist Press.

Manuaba, A. (2009). Dengan Eco Tourism Membangun Bali Lestari. In N. S. Arida (Ed.), Meretas Jalan Ekowisata Bali: Proses Pengembangan, Partisipasi Lokal, Dan Tantangan Ekowisata Di Tiga Desa Kuno Bali. Denpasar: Udayana University Press.

Perry, W. J. (1918). The Megalithic Culture of Indonesia. Manchester: University Press.

Picard, M. (2006). Bali Pariwisata Budaya dan Budaya Pariwisata. Jakarta: Kepustakaan Populer Gramedia (KPG).

Poesponegoro, M. D., \& Notosusanto, N. (1984). Sejarah Nasional Indonesia Jilid I: Zaman Prasejarah di Indonesia (R. P. Soejono, Ed.). Jakarta: Balai Pustaka.

Poesponegoro, M. D., \& Notosusanto, N. (2009). Sejarah Nasional Indonesia 1, Zaman Prasejarah di Indonesia (R. P. Soejono, Ed.). Jakarta: Balai Pustaka.
Pratomo, I. (2014). Potensi Geologi Kawasan Kaldera Toba. Sosialisasi Geologi Untuk Guru-Guru Geografi SeKawasan Danau Toba. Prapat: Badan Geologi.

Ritzer, G., \& Smart, B. (2011). Hand Book Teori Sosial. Jakarta: Nusa Media.

Schnitger, F. M. (1939). Les monuments mégalithiques de Nias. Revue Des Arts Asiatiques, 13(2), 78-84.

Simanjuntak, B. A. (2006). Struktur Sosial dan Sistem Politik Batak Toba Hingga 1945. Jakarta: Yayasan Obor Indonesia.

Simanjuntak, B. A. (2015). Arti dan fungsi tanah bagi masyarakat Batak Toba, Karo, Simalungun (Edisi Pembaruan). Jakarta: Yayasan Pustaka Obor Indonesia.

Soejono, R. P. (1989). Beberapa Masalah tentang Tradisi Megalitik. Pertemuan Ilmiah Arkeologi V. Yogyakarta: Pusat Penelitian Arkeologi Nasional.

Soejono, R. P. (2008). Sistem-Sistem Penguburan pada Akhir Masa Prasejarah di Bali. Jakarta: Pusat Penelitian dan Pengembangan Arkeologi Nasional.

Surbakti, K. (2017). Kebijakan Pengelolaan Warisan Budaya Ditinjau dari Undang-Undang Nomor 11 Tahun 2010 (Perihal Pemberian Insentif dan Kompensasi). Kapata Arkeologi, 13(2), 141-150.

Sutaba, I. M. (2001). Tahta Batu Prasejarah di Bali, Telaah tentang Bentuk dan Fungsinya. Yogyakarta: Yayasan Mahavhira.

Sztompka, P. (2010). Sosiologi Perubahan Sosial. Jakarta: Prenada Media Group.

UU RI. Undang-Undang tentang Cagar Budaya., Pub. L. No. 11 (2010).

Van Bemmelen, R. W. (1970). The Geology of Indonesia. Den Haag: Nijhoff.

Wiradnyana, K. (2015). Paradigma Perubahan Evolusi pada Budaya Megalitik di Wilayah Budaya Nias. Kapata Arkeologi, 11(2), 87-96.

Wiradnyana, K. (2017). Mereposisi Fungsi Menhir dalam Tradisi Megalitik Batak Toba. Sangkhakala Berkala Arkeologi, 20(1), 33-47.

Wiradnyana, K. (2018). Michel Faocault, Arkeologi Pengetahuan dan Pengetahuan Arkeologi. Jakarta: Yayasan Pustaka Obor Indonesia.

Wiradnyana, K. (2019). Arkeologi dan Nilai Penting. Jakarta: Yayasan Obor Indonesia.

Wiradnyana, K., Koestoro, L. P., Setiawan, T., Siahaan, P. H. H., \& Purnawibowo, S. (2016). Berita Penelitian Arkeologi No. 30: Menyusuri Jejak Peradaban Masa Lalu Pulau Samosir. Medan: Balai Arkeologi Sumatera Utara.

Wiradnyana, K., \& Setiawan, T. (2013). Wisata Arkeologi Jejak Peninggalan Tradisi Megalitik di Kabupaten Samosir. Samosir: Dinas Pariwisata, Seni, dan Budaya Kabupaten Samosir.

World Imagery by ESRI. (2020). World Imagery source: Esri, Maxar, GeoEye, Earthstar Geographics, CNES/Airbus DS, USDA, USGS, AeroGRID, IGN, and the GIS User Community. 